\title{
Potentially toxic elements determination and chemical-microbiological analysis of potable water in Taxco de Alarcón, Guerrero
}

\section{Guadalupe Sánchez-Montoya ${ }^{1}$, Oscar Talavera-Mendoza ${ }^{1, *}$, Giovanni Hernández-Flores ${ }^{2, *}$, Elvia Díaz-Villaseñor ${ }^{1}$, Alejandro H. Ramírez-Guzmán ${ }^{1}$, and Zeferino Galarza-Brito ${ }^{1,3}$}

\author{
${ }^{1}$ Escuela Superior de Ciencias de la Tierra, Universidad Autónoma de Guerrero, \\ Ex hacienda San Juan Bautista s/n, Taxco el Viejo, Guerrero, CP 40323, Mexico. \\ ${ }^{2}$ CONACYT - Escuela Superior de Ciencias de la Tierra, Universidad Autónoma de Guerrero, \\ Ex hacienda San Juan Bautista s/n, Taxco el Viejo, Guerrero, CP 40323, Mexico. \\ ${ }^{3}$ Present address: Universidad Nacional Autónoma de México, Instituto de Biotecnología, Cuernavaca, Morelos, 62250, Mexico. \\ *otalavera.uagro@gmail.com; gioheflo_10@hotmail.com
}

\begin{abstract}
Taxco de Alarcón is an important mining site in Mexico. The town is a well-known tourist destination where the potable water quality is important for guaranteeing the health of the users. Due to the altitude of the city, the surface and rain water are the main sources of water. Thus, the aims of this study were to characterize i) the composition and chemical speciation of particulate matter suspended in water to determine the content of potentially toxic elements, and ii) the chemical and bacteriological composition of the potable water of Taxco de Alarcón, Guerrero, Mexico, according to the Mexican official norm NOM-127-SSA1-1994.

The analyzed representative samples were taken from the municipal water distribution network, the water treatment plant, the Chacuhalco spring and a mixture of the waters of the Chontalcuatlán river, the Tenería spring, and the San Marcos and El Sombrerito dams. According to the results, $94 \%$ of the analyzed samples did not comply with the standard NOM-127-SSA1-1994. Moreover, the distribution of the analyzed elements in the different chemical fractions of the particulate matter showed that the highest concentration of Cd (4.17 $\left.\mathrm{mg} \cdot \mathrm{kg}^{-1}\right)$ is associated with the carbonate fraction. This means Cd is moderately bioavailable. On the other hand, the highest concentrations of $\mathrm{Pb}, \mathrm{Zn}, \mathrm{Mn}$ and $\mathrm{Cu}\left(62.2,42.3,243\right.$ and $1026 \mathrm{mg} \cdot \mathrm{kg}^{-1}$, respectively) were detected in the $\mathrm{Fe}-\mathrm{Mn}$ oxyhydroxide fraction, also considered as moderately bioavailable, whereas the highest concentrations of As, $\mathrm{Fe}$ and $\mathrm{V}\left(24.0,7583\right.$ and $31.3 \mathrm{mg} \cdot \mathrm{kg}^{-1}$, respectively) were associated with the residual fraction, considered as non-bioavailable.
\end{abstract}

The results indicate that, to improve the quality of potable water, modifications must be incorporated along the water treatment processes, and in the distribution network and management.

Key words: chemical speciation; Hydrogeochemistry; Mexico; particulate matter; potable water; Taxco de Alarcón; water quality.

\section{RESUMEN}

Taxco de Alarcón es una importante ciudad con una amplia tradición minera en México. La ciudad es uno de los destinos turísticos más importantes del país donde la calidad del agua es importante para garantizar la salud de los usuarios. Debido a la altitud de la ciudad, el agua de lluvia y agua superficial son las principales fuentes de abastecimiento. Por esta razón, los objetivos de este estudio fueron: i) caracterizar la composición y especiación química del material particulado suspendido en el agua para determinar el contenido de elementos potencialmente tóxicos y ii) analizar química y bacteriológicamente el agua potable de Taxco de Alarcón, Guerrero, México de acuerdo con la norma oficial mexicana NOM-127-SSA1-1994.

Las muestras representativas fueron tomadas y analizadas a partir de la red de distribución de agua municipal, la planta potabilizadora, el manantial Chacuhalco y una mezcla de agua compuesta por agua del río Chontalcuatlán, el manantial de Tenería y las presas San Marcos y El Sombrerito.

Los resultados muestran que el $94 \%$ de las muestras analizadas no

Sánchez-Montoya, G., Talavera-Mendoza, O., Hernández-Flores, G., Díaz-Villaseñor, E., Ramírez-Guzmán, A.H., Galarza-Brito, Z., 2019, Potentially toxic elements determination and chemical-microbiological analysis of potable water in Taxco de Alarcón, Guerrero: Revista Mexicana de Ciencias Geológicas, v. 36, núm. 2, p. 147-158. 
cumplen con la NOM-127-SSA1-1994. Además, la distribución de los elementos analizados en las diferentes fracciones químicas del material particulado mostró que la concentración más alta de Cd (4.17 $\left.\mathrm{mg} \cdot \mathrm{kg}^{-1}\right)$ está asociada con la fracción de carbonatos; es decir, el Cd es moderadamente biodisponible. Por otro lado, las concentraciones más altas de $\mathrm{Pb}, \mathrm{Zn}, \mathrm{Mn}$ y $\mathrm{Cu}$, de 62.2, 42.3, 243 y $1026 \mathrm{mg} \mathrm{kg}^{-1}$, respectivamente, fueron detectadas en la fracción de oxihidróxidos de Fe-Mn, también considerada como moderadamente biodisponible, mientras que las concentraciones más elevadas de As, Fe y V (24.0, 7583 y $31.3 \mathrm{mg} \cdot \mathrm{kg}^{-1}$, respectivamente) se encuentran asociadas con la fracción residual, considerada como no biodisponible.

En general, los resultados indican que se deben realizar modificaciones a lo largo del proceso de tratamiento, en la red de distribución y en el almacenamiento para poder mejorar la calidad del agua suministrada en la Ciudad de Taxco de Alarcón, Guerrero.

Palabras clave: agua potable; calidad del agua; especiación química; Hidrogeoquímica; material particulado; México; Taxco de Alarcón.

\section{INTRODUCTION}

For many centuries, the provision of good quality water has been a determining factor for both subsistence and the society economy $(\mathrm{Qu}$ et al., 2013). Nevertheless, although the percent of freshwater available is low (0.5\%), their unsuitable use and the detriment of the water quality is a common phenomenon around the world (CONAGUA, 2016; Sun et al., 2017). Water pollution depicts one of the most alarming environmental problems in the contemporary world (Pulido-Bosch, 2007; Hernández-Flores et al., 2017). In many countries, particularly those with emerging economies, anthropogenic activities related to population growth, industrial development, mining, the excessive use of fertilizers, pesticides and insecticides makes the water unusable for any human activity (Cifuentes et al., 1994; Literathy, 1996; GómezÁlvarez et al., 2004; Sjömander Magnusson and van der Merwe, 2005; Gordillo-Martínez et al., 2010; Lu, 2011).

In Mexico, some states with important mining activity such as Zacatecas, San Luis Potosí, Guerrero and Sonora have been affected by the pollution by heavy metals $(\mathrm{Hg}, \mathrm{Ar}, \mathrm{Pb}$ and $\mathrm{Cr}$ ) attributed to the mining industry and effected by the inadequate management of solid mining wastes (Covarrubias and Peña Cabriales, 2017; Corona-Chávez et al., 2017). On the other hand, INEGI (2013) reported that the surface water or shallow groundwater represents the main source of domestic water supply for a large number of rural populations and many cities in Mexico. Even raw or superficial shallow groundwater without any treatment is still used for human consumption, which may represent a risk to the health of the inhabitants.

Taxco de Alarcón ( $T x-A)$, Guerrero, México (18³ $33^{\prime} 24^{\prime \prime} \mathrm{N} ; 99^{\circ}$ $\left.36^{\prime} 17^{\prime \prime} \mathrm{W}\right)$, recognized as a city of mining origin founded in the midseventeenth century is considered a major tourist destination (CRM, 1999; Des Rivières and Beals, 2011). From the $20^{\text {th }}$ century on, mining in Taxco has been centered on base metals $\mathrm{Pb}, \mathrm{Cu}, \mathrm{Zn}$ and precious metals such as Ag and Au. Unfortunately, linked to their production processes, some elements such as As and heavy metals (potentially toxic elements) were produced and released into the environment in waste. Those pollutants are present in the liquid and solid mining waste disposed in the surrounding environment of $T x-A$, where the wind, animals and the rain are some of the possible dispersion factors, altering the properties of the soil and water (Romero et al., 2007; Talavera-Mendoza et al., 2016; Corrales-Pérez and Martín-Romero, 2018).

The city has several different water sources. The main source of supply is the surface water of the Chontacuatlán river captured at $18^{\circ} 39^{\prime} 15^{\prime \prime} \mathrm{N} ; 99^{\circ} 34^{\prime} 27^{\prime \prime} \mathrm{W}$. Other supply sources of $T x$ - $A$ are the springs of Chacuhalco and Tenería, and the San Marcos and El Sombrerito dikes (known as dams). These dikes are located in the recharge zone and, therefore, their capturing capacity is very low. In addition, these dikes are located in areas where the hydraulic load is very high, i.e. where the difference between the level of stored water and the water flow of the Chontalcuatán River is almost $1 \mathrm{~km}$.

In most cities, potable water is treated in treatment plants that aim to eliminate pathogenic contaminants and microbes that may potentially harm the health of users. The methods used as well as the efficiency of the process determine the quality of the water that is sent to different places, and finally determine the use for which it is destined. The evaluation of the chemical and microbiological composition of potable water for human consumption, as well as of the chemical composition of suspended particulate matter is an imperative need, not only for determining the water quality but also to evaluate the efficiency of the treatment methods used.

The city of $T x-A$ has a water treatment plant (WTP) (Figure 1). The water processed in the WTP comes from the Chontalcuatlán river, the Chacuhalco and Tenería springs, and the San Marcos and El Sombrerito dams. According previous analysis, the water of the Chacuhalco spring shows good quality and presents levels of turbidity below the NOM-127-SSA1-1994 standard (Secretaría de Salud, 2000); therefore, water enters directly to the chlorination stage of the WTP. The water from the other sources is collected in a mixing box before being treated. $T x-A$ treatment plant uses the pitcher method to determine the amount of flocculant aluminum sulphate $\mathrm{Al}_{2}\left(\mathrm{SO}_{4}\right)_{3}$ to be added by adjusting, for this, the $\mathrm{pH}$ of the water between 6.5 and 7.5 with $20 \% \mathrm{CaO}$ and $\mathrm{HCl}$ solutions.

The WTP, as many others around the world, is not designed to treat the pollution caused by mining waste and the risk of the presence of this type of pollutants is high. The pollution of water by $\mathrm{As}, \mathrm{Cd}, \mathrm{Pb}, \mathrm{Hg}$, $\mathrm{Tl}$, among other toxic elements, related to biomagnification of these elements from solid and liquid mining wastes close to urban settlements is an issue of public health concern (Smith and Huyck, 1999; Massoudieh et al., 2010; Talavera-Mendoza et al., 2016).

Thus, due to the importance of this city, its proximity to the mining solid wastes, and the fact that surface water is the main source for supply, we performed this study with the aim of characterize $i$ ) the composition and chemical speciation of particulate matter suspended in water to determine the content of potentially toxic elements, and $i i$ ) the chemical and bacteriological composition of the potable water of $T x-A$, according to the Mexican official standard NOM-127-SSA1-1994.

\section{MATERIALS AND METHODS}

Thirty-three water samples from the Taxco de Alarcón city were analyzed (Figure 2). One raw water sample comes from the Chacuhalco spring (sample 1, Figure 2), and the second sample is a mixture of water of the Chontalcuatlán river, the Teneria spring, and the San Marcos and El Sombrerito dams (sample 2, Figure 2). The third sample was taken from the WTP output (sample 3, Figure 2). Finally, thirty samples come from the water distribution network collected directly from the tap (samples 4-33, Figure 2). The source of the treated water, and the treatment method have remained the same for a decade. Sampling was carried out in July 2007, at the beginning of the rainy season. The selection of sampling points was random; in Figure 2, the sampling points are located on a map of the city of $T x-A$.

At each sampling site, the temperature, $\mathrm{pH}$, Eh and electrical conductivity were determined. Temperature and $\mathrm{pH}$ were measured by potentiometry with an Oakton portable $\mathrm{pH}$ meter. The Eh was measured 


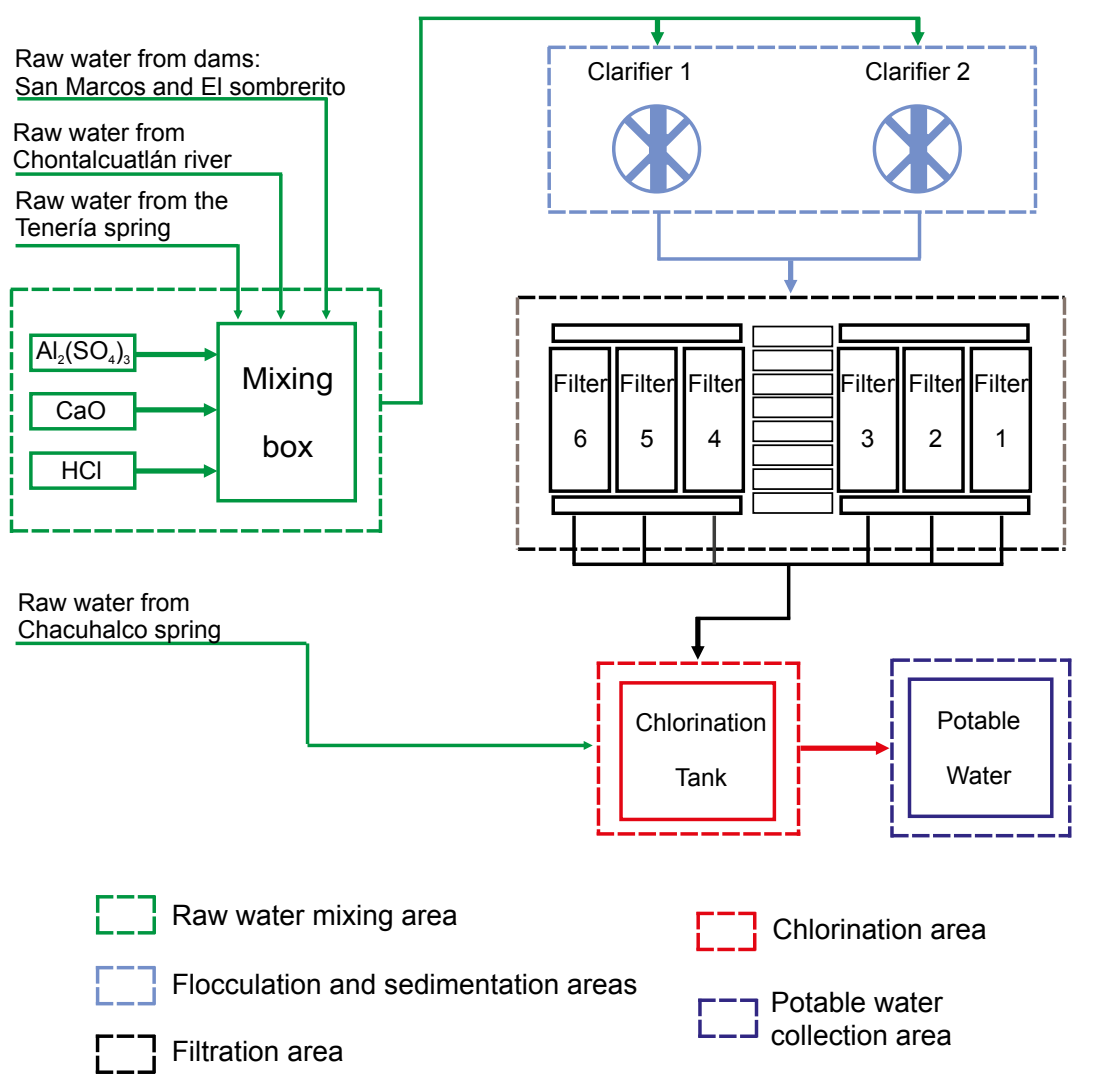

Figure 1. Schematic diagram of the purification process in the Taxco de Alarcón water treatment plant.

with a Cole-Parmer model waterproof ORPtestr Double Junction. Conductivity was measured with a Horiba Model ES-14 E conductivity meter with automatic temperature compensation and stabilization.

Three aliquots were taken at each point, two of them in Nalgene ${ }^{\mathrm{Tx}}$ high density polypropylene bottles prewashed with diluted $\mathrm{HNO}_{3}$, deionized water and tempered with the sample water. For the bacteriological analyzes, a $250 \mathrm{~mL}$ aliquot was taken in sterile containers. The collected samples were placed in a cooler at $<15^{\circ} \mathrm{C}$ and transported to the laboratory for analysis at the end of the day. To determine the anions, the aliquot was $1 \mathrm{~L}$, whereas for the analysis of the metals the aliquot was $500 \mathrm{~mL}$ acidified with $2 \mathrm{~mL}$ of ultrapure concentrated $\mathrm{HNO}_{3}$ (Ultrex II).

The alkalinity was determined by the titration method with $0.02 \mathrm{M} \mathrm{HCl}$ using phenolphthalein, bromocresol green, and methyl red as colorimetric indicators. The chlorides were determined by titration with $0.02 \mathrm{M} \mathrm{AgNO}_{3}$ and $0.04 \mathrm{M} \mathrm{K}_{2} \mathrm{CrO}_{4}$. The sulfate $\left(\mathrm{SO}_{4}{ }^{2-}\right)$, nitrate $\left(\mathrm{NO}_{3}{ }^{-}\right.$as $\left.\mathrm{N}\right)$, fluorine $\left(\mathrm{F}^{-}\right)$and turbidity contents were analyzed by colorimetry using a $\mathrm{HACH}$ model $\mathrm{DR} / 890 . \mathrm{BaCl}_{2}$ and citric acid were used for the sulfates; for the nitrates a cadmium reduction reagent was used, whereas for the fluoride SPANDS was used. Only absorbence was measured for turbidity, comparing it with a target.

Bacteriological analysis was performed by the $0.45 \mu \mathrm{m}$ cellulose acetate membrane filtration method using ampoules with Hach's $\mathrm{m}$-ColiBlue $24^{\circledR}$ - culture medium. The bacteria were incubated in a ColeParmer 52100-100 convection oven at a temperature of $37^{\circ} \mathrm{C}$ for $24 \mathrm{~h}$.

The cations concentration was determined in acidified and filtered samples $(0.45 \mu \mathrm{m}$ cellulose acetate) by the technique of inductively coupled plasma atomic emission spectroscopy (ICP-AES) in a Perkin Elmer, Optima 3200 DV. Sodium was analyzed on a 100 Perkin Elmer
AAnalyst 800 Atomic Absorption Spectrometer. During the analysis, four certified High-Purity water standards (CWW-TM-D; CWWTM-H; CWW-TM-A and CWW-TM-E) were used.

On the other hand, to assess the presence, concentration and bioavailability of toxic metals in the water, the extractable metal content was determined treating $1.0 \mathrm{~g}$ of suspended particulate matter obtained from sample 13 (Figure 2) with concentrated $\mathrm{HNO}_{3}$ (assuming that the nature of the particulate is the same in all the samples). Furthermore, to establish the potential release effect of toxic elements of suspended material in potable water with greater precision, a sequential extraction of metals from the particulate was carried out following the methodology proposed by Tessier et al. (1979). It has been shown that the presence of toxic metals (total or partial concentration) in particulate matter does not necessarily mean that they are bioavailable (Tessier et al., 1979) and, therefore, have harmful effects on biota or man. The bioavailability of an element depends largely on the chemical species in which it is found. For example, high concentrations of $\mathrm{Cd}$ in a sulfur phase with low solubility will be less bioaccessible than very low concentrations of $\mathrm{Cd}$ in a water-soluble phase. For this reason, the understanding of the fraction in which a particular metal is associated and its concentration provides more information on the bioavailability of the metal and, therefore, a better approximation to the true impact on health. According to Tessier et al. (1979), the metals can be separated into five chemical fractions: 1) exchangeable fraction (soluble + adsorbed); 2) fraction bound to carbonates; 3 ) fraction associated with oxyhydroxides of Fe-Mn; 4) fraction bound to sulfides and organic matter, and 5) residual fraction (insoluble). Total metals and sequential extraction solutions were analyzed in an ICP-AES Perkin-Elmer, optima 3200 DV (Talavera-Mendoza et al., 2016). 


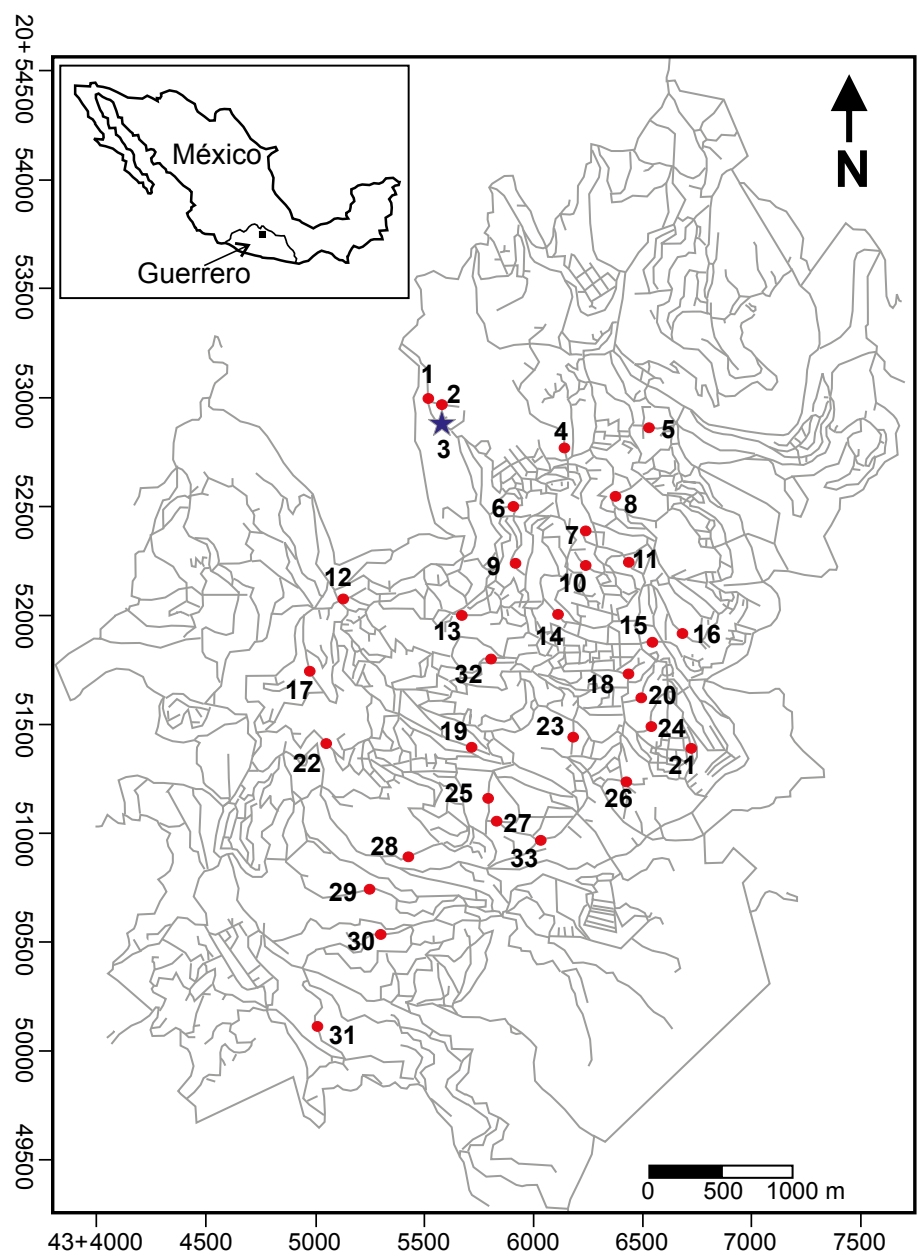

Figure 2. Map of the urban area of Taxco de Alarcón, Guerrero, showing the location of the municipal water treatment plant (blue star), collection sites of samples of raw water (red circles labeled 1 and 2) and household tap water (red circles labeled 3-33).

\section{RESULTS}

\section{Physicochemical and bacteriological characteristics of water samples}

Raw water

The real detection limits (DL) reported by Talavera-Mendoza et al. (2006) were used for water samples analyzed under the same analytical conditions, on the same equipment and using the same sample preparation procedure (Table 1, Table 2).

The temperature of the water of Chacuhalco spring (sample 1; Figure 2) was $19.6^{\circ} \mathrm{C}$; the $\mathrm{pH}$ was almost neutral (6.6) and the Eh was $551 \mathrm{mV}$ indicating high oxygenation. The conductivity of Chacuhalco water was $0.103 \mathrm{mS} \mathrm{cm}^{-1}$ and reflects low dissolved solids content. Water has a low turbidity ( $8 \mathrm{NTU}$ ) and is characterized by contents of $\mathrm{SO}_{4}{ }^{2-}$ and $\mathrm{Cl}^{-}<\mathrm{DL}$ and low values of $\mathrm{HCO}_{3}{ }^{-}, \mathrm{NO}_{3}-\mathrm{N}, \mathrm{F}^{-}, \mathrm{Na}^{+}, \mathrm{Ca}^{2+}$, $\mathrm{Mg}^{2+}$ and $\mathrm{K}^{+}$(Table 1). The hydrogeochemistry of the Chacuhalco spring shows that the water has values of turbidity just above that established in NOM-127-SSA1-1994. The concentration of the majority of the measured metals is below the DL except for $\mathrm{Sr}\left(0.038 \mathrm{mg} \cdot \mathrm{L}^{-1}\right)$, $\mathrm{Zn}\left(0.402 \mathrm{mg} \cdot \mathrm{L}^{-1}\right), \mathrm{Al}\left(0.100 \mathrm{mg} \cdot \mathrm{L}^{-1}\right)$ and $\mathrm{Ba}\left(0.609 \mathrm{mg} \cdot \mathrm{L}^{-1}\right)$ (Table 2$)$. Bacteriological analysis indicates that Chacuhalco spring water presents eight colony-forming units (CFU) of total coliforms (TC) (Table 3). This means that the water is not suitable for human consumption, and yet, this water is not treated in the WTP and is only chlorinated before sending it to the homes.

On the other hand, the mixed sample of the Chontalcuatlán river, the Teneria spring, and the San Marcos and El Sombrerito dams (sample 2) has a slightly basic pH (8.4) and an Eh of $426 \mathrm{mV}$, which indicates an oxidizing environment. The conductivity of this water was moderate $\left(0.636 \mathrm{mS} \cdot \mathrm{cm}^{-1}\right)$ and therefore the total dissolved solids (TDS) are also moderate $\left(434 \mathrm{mg} \cdot \mathrm{L}^{-1}\right)$. Turbidity is low (5 NTU). Sample 2 has low anion and cation contents (Table 1). With the exception of $\mathrm{Ba}\left(0.935 \mathrm{mg} \cdot \mathrm{L}^{-1}\right)$, all metals are within the NOM-127-SSA1-1994, and even $\mathrm{Cu}, \mathrm{Ag}, \mathrm{Mn}, \mathrm{Cd}, \mathrm{Co}, \mathrm{Ni}, \mathrm{Pb}, \mathrm{Se}$, and $\mathrm{V}$ are found $<\mathrm{DL}$ of the method (Table 2). In the bacteriological analysis, more than $20 \mathrm{CFU} / 100 \mathrm{~mL}$ of E. coli and more than 100 CFU/100 mL of TC were found (Table 3). The results indicate that this water does not meet the specifications of NOM-127-SSA1-1994.

\section{Treated water}

The water sample treated at the WTP (sample 3, Figure 2) showed a slightly acid $\mathrm{pH}$ (5.7). The Eh was $885 \mathrm{mV}$ which indicates that the water is highly oxygenated. It also has low conductivity $\left(0.136 \mathrm{mS} \mathrm{cm}^{-1}\right)$ and consequently low TDS (92 $\left.\mathrm{mg} \cdot \mathrm{L}^{-1}\right)$, whereas the turbidity is high (32 NTU).

Sample 3 is characterized by low content of $\mathrm{HCO}_{3}{ }^{-}, \mathrm{Cl}^{-}, \mathrm{SO}_{4}{ }^{2-}$, $\mathrm{NO}_{3}-\mathrm{N}, \mathrm{F}^{-}, \mathrm{Na}^{+}, \mathrm{K}^{+}, \mathrm{Ca}^{2+}$, and $\mathrm{Mg}^{2+}$ (Table 1). Moreover, concentra- 
Table 1. Physicochemical characteristics of water samples from Taxco de Alarcón, Guerrero.

\begin{tabular}{|c|c|c|c|c|c|c|c|c|c|c|c|c|c|c|c|c|c|c|}
\hline \multirow{2}{*}{\multicolumn{2}{|c|}{ Sample pH }} & Cond $^{\mathrm{a}}$ & Turbidity & Temp $^{\text {b }}$ & $\mathbf{E h}^{\mathrm{c}}$ & $\mathrm{NO}_{3}^{-}-\mathrm{N}$ & $\mathrm{HCO}_{3}^{-}$ & $\mathrm{CO}_{3}^{2-}$ & $\mathrm{Cl}^{-}$ & $\mathrm{SO}_{4}{ }^{2-}$ & $\mathrm{SiO}_{2}$ & $\mathbf{F}^{-}$ & $\mathrm{Na}^{+}$ & $\mathbf{K}^{+}$ & $\mathrm{Ca}^{2+}$ & $\mathbf{M g}^{2+}$ & TDS $^{\mathbf{d}}$ & Hardness \\
\hline & & $\mathrm{mS} \cdot \mathrm{cm}^{-1}$ & $\mathrm{NTU}^{\mathrm{e}}$ & ${ }^{\circ} \mathrm{C}$ & $\mathrm{mV}$ & $\mathrm{mg} \cdot \mathrm{L}^{-1}$ & $\mathrm{mg} \cdot \mathrm{L}^{-1}$ & $\mathrm{mg} \cdot \mathrm{L}^{-1}$ & $\mathrm{mg} \cdot \mathrm{L}^{-1}$ & $\mathrm{mg} \cdot \mathrm{L}^{-1}$ & $\mathrm{mg} \cdot \mathrm{L}^{-1}$ & $\mathrm{mg} \cdot \mathrm{L}^{-1}$ & $\mathrm{mg} \cdot \mathrm{L}^{-1}$ & $\mathrm{mg} \cdot \mathrm{L}^{-1}$ & $\mathrm{mg} \cdot \mathrm{L}^{-1}$ & $\mathrm{mg} \cdot \mathrm{L}^{-1}$ & $\mathrm{mg} \cdot \mathrm{L}^{-1}$ & $\mathrm{mg} \cdot \mathrm{L}^{-1}$ \\
\hline$D L^{f}$ & -- & -- & 1.0 & -- & -- & 0.100 & 5.0 & 5.0 & 1.00 & 1.00 & 5.0 & 0.010 & 0.050 & 0.050 & 0.050 & 0.050 & -- & -- \\
\hline 1 & 6.6 & 0.103 & 8 & 19.6 & 551 & 0.2 & 70.8 & $<\mathrm{DL}$ & $<\mathrm{DL}$ & $<\mathrm{DL}$ & 75.9 & 0.11 & 10.1 & 3.0 & 12.6 & 0.2 & 133 & 32.4 \\
\hline 2 & 8.4 & 0.636 & 5 & 18.5 & 426 & 2.4 & 187 & 10 & 9.6 & 70.0 & 38.9 & 0.44 & 63.5 & 7.4 & 54.9 & 11 & 434 & 182.5 \\
\hline 3 & 5.7 & 0.136 & 32 & 22.1 & 885 & 0.8 & 4.9 & $<\mathrm{DL}$ & 5.2 & 45.6 & 24.9 & 0.03 & 5.6 & 2.6 & 10.8 & 1.9 & 92 & 34.6 \\
\hline 4 & 7.3 & 0.299 & 21 & 19.7 & 714 & 0.8 & 70.8 & $<\mathrm{DL}$ & 30.5 & 49.5 & 37.8 & 0.17 & 19.6 & 4.1 & 24.7 & 6.1 & 227 & 86.6 \\
\hline 7 & 7.8 & 0.407 & 93 & 23.1 & 473 & 0.9 & 75.6 & $<\mathrm{DL}$ & 46.1 & 61.7 & 26.3 & 0.19 & 26.0 & 4.6 & 31.4 & 5.9 & 268 & 103.0 \\
\hline 8 & 7.8 & 0.312 & 4 & 20.6 & 532 & 1.0 & 63.4 & $<\mathrm{DL}$ & 35.7 & 58.5 & 32.8 & 0.21 & 21.7 & 4.3 & 27.1 & 6.0 & 237 & 92.4 \\
\hline 9 & 7.4 & 0.319 & 10 & 20.8 & 730 & 0.9 & 56.1 & $<\mathrm{DL}$ & 33.1 & 70.5 & 35.3 & 0.30 & 19.7 & 4.1 & 25.9 & 6.5 & 237 & 91.4 \\
\hline 10 & 6.3 & 0.161 & 7 & 20.8 & 514 & 0.8 & 14.6 & $<\mathrm{DL}$ & 12.2 & 45.7 & 24.8 & 0.08 & 8.4 & 2.6 & 12.6 & 2.3 & 114 & 40.8 \\
\hline 11 & 5.2 & 0.132 & 18 & 22.9 & 964 & 0.6 & 9.8 & $<\mathrm{DL}$ & 9.6 & 47.1 & 24.2 & ND & 7.0 & 2.4 & 9.9 & 1.6 & 101 & 31.4 \\
\hline 12 & 8.1 & 0.079 & 34 & 19.8 & 422 & 0.5 & 122.0 & $<\mathrm{DL}$ & 2.7 & 14.3 & 32.4 & 0.03 & 3.5 & 2.5 & 10.1 & 0.6 & 173 & 27.9 \\
\hline 17 & 7.6 & 0.076 & 20 & 19.6 & 425 & 0.6 & 39 & $<\mathrm{DL}$ & $<\mathrm{DL}$ & 10.3 & 30.7 & ND & 3.1 & 2.6 & 9.1 & 0.8 & 83 & 25.8 \\
\hline 18 & 7.5 & 0.314 & 19 & 22.6 & 486 & 0.7 & 56.1 & $<\mathrm{DL}$ & 34.2 & 9.8 & 33.5 & 0.05 & 21.6 & 4.0 & 27.8 & 5.8 & 178 & 93.1 \\
\hline 19 & 7.9 & 0.269 & 3 & 21.1 & 495 & 0.6 & 48.8 & $<\mathrm{DL}$ & 27.0 & 66.1 & 27.6 & 0.10 & 16.3 & 3.9 & 25.2 & 3.4 & 206 & 76.9 \\
\hline 20 & 7.1 & 0.237 & 20 & 24.1 & 504 & 0.7 & 51.2 & $<\mathrm{DL}$ & 26.1 & 40.0 & 29.5 & 0.07 & 15.3 & 3.3 & 20.1 & 4.3 & 177 & 67.7 \\
\hline 21 & 8.2 & 0.35 & 5 & 22.1 & 504 & 1.1 & 80.5 & $<\mathrm{DL}$ & 34.8 & 59.6 & 32.7 & 0.12 & 21.5 & 4.6 & 32.2 & 5.7 & 259 & 104.0 \\
\hline 22 & 8.1 & 0.143 & 43 & 21.7 & 878 & 0.8 & 63.4 & $<\mathrm{DL}$ & 17.4 & 17.6 & 31.6 & ND & 11.2 & 3.2 & 11.2 & 0.8 & 143 & 31.1 \\
\hline 23 & 6.2 & 0.141 & 32 & 22.1 & 902 & 06 & 12.2 & $<\mathrm{DL}$ & 14.0 & 34.5 & 24.1 & ND & 7.4 & 2.8 & 10.1 & 2.1 & 97 & 33.8 \\
\hline 24 & 7.8 & 0.277 & 9 & 22.9 & 549 & 0.8 & 43.9 & $<\mathrm{DL}$ & 24.4 & 69.3 & 29.1 & 0.14 & 13.7 & 4.5 & 24.5 & 5.3 & 203 & 82.8 \\
\hline 25 & 7.8 & 0.223 & 15 & 23.4 & 476 & 0.9 & 43.9 & $<\mathrm{DL}$ & 20.1 & 39.1 & 31.2 & 0.09 & 12.7 & 4.4 & 19.3 & 3.7 & 162 & 63.5 \\
\hline 26 & 8.3 & 0.135 & 3 & 22.2 & 596 & 0.7 & 68.3 & $<\mathrm{DL}$ & 7.0 & 8.5 & 30.6 & ND & 8.5 & 3.3 & 12.8 & 1.7 & 127 & 39.0 \\
\hline 27 & 8.1 & 0.442 & 5 & 22.9 & 453 & 1.0 & 95.2 & $<\mathrm{DL}$ & 63.5 & 56.7 & 29.8 & 0.14 & 36.8 & 6.9 & 30.6 & 6.4 & 314.0 & 103.0 \\
\hline
\end{tabular}

Notes: ${ }^{\mathrm{a} C o n d u c t i v i t y ; ~}{ }^{\mathrm{b}}$ Temperature; ${ }^{\mathrm{C}}$ Redox potential; ${ }^{\mathrm{d}}$ Total dissolved solids; ${ }^{\mathrm{e}}$ Nephelometric transfer units; ${ }^{\mathrm{f}}$ Detection limit; ${ }^{\mathrm{g}}$ Not detected; Data values have a standard deviation less than $5 \%$.

tions of $\mathrm{As}, \mathrm{Ag}, \mathrm{Cd}, \mathrm{Co}, \mathrm{Cu}, \mathrm{Ni}, \mathrm{Pb}, \mathrm{Se}$ and $\mathrm{V}$ are $<\mathrm{DL}$ of the method, whereas the contents of $\mathrm{Fe}, \mathrm{Sr}, \mathrm{Zn}, \mathrm{Mn}$ and Ba were low (Table 2). Furthermore, bacteriological analysis indicates that the treated water does not contain E. coli or TC (Table 3). Therefore in sample 3, the parameters that do not meet the NOM-127-SSA1-1994 standard are $\mathrm{pH}$, turbidity and $\mathrm{Al}$ content. The acidity of the water is probably due to the chlorination process. On the other hand, the high values of turbidity and $\mathrm{Al}$ content are due to the inefficiency of the flocculation process during the treatment process.

\section{Water from the distribution network}

The temperatures of the household samples 4 to 33 (Figure 2) range between 18.6 and $24.4^{\circ} \mathrm{C}$. The $\mathrm{pH}$ in the household samples displays significant variations, ranging from 5.2 to 8.8 . Half of the samples have slightly basic $\mathrm{pH}$ values (7.5-9.0), $40 \%$ have circum-neutral $\mathrm{pH}$ values (7.5 - 6.5) and only $10 \%$ have slightly acidic $\mathrm{pH}$ values (6.5-5.5). The Eh values are variable and range from 373 to $964 \mathrm{mV}$ (Table 1). Conductivity varies between 0.076 and $0.442 \mathrm{mS} \cdot \mathrm{cm}^{-1}$, which translates into TDS between 70 and $314 \mathrm{mg} \cdot \mathrm{L}^{-1}$. The turbidity of the samples is also variable and ranges from 3 to 93 NTU.
The $\mathrm{HCO}_{3}{ }^{-}$contents were variable and range from 9.7 to $122.0 \mathrm{mg} \cdot \mathrm{L}^{-1}$. The contents of $\mathrm{SO}_{4}{ }^{2-}\left(1.1-70.5 \mathrm{mg} \cdot \mathrm{L}^{-1}\right)$ and of $\mathrm{Cl}^{-}\left(0.9-63.5 \mathrm{mg} \cdot \mathrm{L}^{-1}\right)$ were low. The contents of $\mathrm{NO}_{3}-\mathrm{N}$ range from 0.5 to $2.0 \mathrm{mg} \cdot \mathrm{L}^{-1}$. The concentrations of $\mathrm{F}^{-}$were very low between $<\mathrm{DL}$ and $0.3 \mathrm{mg} \cdot \mathrm{L}^{-1}$.

The content of $\mathrm{Ca}^{2+}$ varied from 9.1 to $35.5 \mathrm{mg} \cdot \mathrm{L}^{-1}$, whereas the concentration of $\mathrm{Mg}^{2+}$ varied between 0.452 and $6.690 \mathrm{mg} \cdot \mathrm{L}^{-1}$. These low concentrations of $\mathrm{Ca}^{2+}$ and $\mathrm{Mg}^{2+}$ translate into a low hardness $(<116$ $\mathrm{mg} \cdot \mathrm{L}^{-1}$ as $\mathrm{CaCO}_{3}$ ). According to the Durfor and Becker (1964) classification, the household tap water is classified as soft to moderately hard water. In general, all samples are characterized by low concentrations of $\mathrm{Na}^{+}\left(2.7-36.7 \mathrm{mg} \cdot \mathrm{L}^{-1}\right)$ and potassium $\mathrm{K}^{+}\left(1.4-6.9 \mathrm{mg} \cdot \mathrm{L}^{-1}\right)$.

The concentrations of $\mathrm{Ag}, \mathrm{Cd}, \mathrm{Co}, \mathrm{Ni}, \mathrm{Pb}, \mathrm{Se}$ and $\mathrm{V}$ in all samples of household water were very low ( $<$ DL of the analytical method used). The concentrations of $\mathrm{Zn}$ range between 0.027 and $0.916 \mathrm{mg} \cdot \mathrm{L}^{-1}$, only three samples were $<$ DL. In most samples, the Mn content was low or $<$ DL (Table 2), and only in five samples was above the detection limit, but with concentrations that are consistently low $\left(0.031-0.088 \mathrm{mg} \cdot \mathrm{L}^{-1}\right)$. On the other hand, the contents of As were equally low since in most samples were $<$ DL. Samples 27, 28 and 30 had concentrations exceeding this limit which varied between 0.011 and $0.018 \mathrm{mg} \cdot \mathrm{L}^{-1}$. The contents of 
Table 2. Concentration of trace elements in water samples from Taxco de Alarcón, Guerrero.

\begin{tabular}{|c|c|c|c|c|c|c|c|c|c|c|c|c|c|c|c|}
\hline \multirow[t]{2}{*}{ Sample } & $\mathrm{Fe}$ & Sr & $\mathrm{Zn}$ & Mn & As & Ag & Al & $\mathrm{Ba}$ & Cd & Co & $\mathrm{Cu}$ & $\mathrm{Ni}$ & $\mathbf{P b}$ & V & Se \\
\hline & $\mathrm{mg} \cdot \mathrm{L}^{-1}$ & $\mathrm{mg} \cdot \mathrm{L}^{-1}$ & $\mathrm{mg} \cdot \mathrm{L}^{-1}$ & $\mathrm{mg} \cdot \mathrm{L}^{-1}$ & $\mathrm{mg} \cdot \mathrm{L}^{-1}$ & $\mathrm{mg} \cdot \mathrm{L}^{-1}$ & $\mathrm{mg} \cdot \mathrm{L}^{-1}$ & $\mathrm{mg} \cdot \mathrm{L}^{-1}$ & $\mathrm{mg} \cdot \mathrm{L}^{-1}$ & $\mathrm{mg} \cdot \mathrm{L}^{-1}$ & $\mathrm{mg} \cdot \mathrm{L}^{-1}$ & $\mathrm{mg} \cdot \mathrm{L}^{-1}$ & $\mathrm{mg} \cdot \mathrm{L}^{-1}$ & $\mathrm{mg} \cdot \mathrm{L}^{-1}$ & $\mathrm{mg} \cdot \mathrm{L}^{-1}$ \\
\hline $\mathbf{D L}^{\mathrm{a}}$ & 0.025 & 0.025 & 0.025 & 0.025 & 0.010 & 0.025 & 0.025 & 0.025 & 0.005 & 0.025 & 0.025 & 0.025 & 0.025 & 0.025 & 0.025 \\
\hline 2 & 0.049 & 0.337 & 0.871 & $<\mathrm{DL}$ & 0.034 & $<\mathrm{DL}$ & 0.135 & 0.935 & $<\mathrm{DL}$ & $<\mathrm{DL}$ & $<\mathrm{DL}$ & $<\mathrm{DL}$ & $<\mathrm{DL}$ & $<\mathrm{DL}$ & $<\mathrm{DL}$ \\
\hline 3 & 0.093 & 0.065 & 0.042 & 0.032 & $<\mathrm{DL}$ & $<\mathrm{DL}$ & 1.820 & 0.076 & $<\mathrm{DL}$ & $<\mathrm{DL}$ & $<\mathrm{DL}$ & $<\mathrm{DL}$ & $<\mathrm{DL}$ & $<\mathrm{DL}$ & $<\mathrm{DL}$ \\
\hline 4 & 0.112 & 0.153 & 0.44 & $<\mathrm{DL}$ & $<\mathrm{DL}$ & $<\mathrm{DL}$ & 0.874 & 0.068 & $<\mathrm{DL}$ & $<\mathrm{DL}$ & $<\mathrm{DL}$ & $<\mathrm{DL}$ & $<\mathrm{DL}$ & $<\mathrm{DL}$ & $<\mathrm{DL}$ \\
\hline 7 & 0.183 & 0.180 & 0.236 & $<\mathrm{DL}$ & $<\mathrm{DL}$ & $<\mathrm{DL}$ & 0.367 & 0.088 & $<\mathrm{DL}$ & $<\mathrm{DL}$ & 0.049 & $<\mathrm{DL}$ & $<\mathrm{DL}$ & $<\mathrm{DL}$ & $<\mathrm{DL}$ \\
\hline 8 & 0.051 & 0.154 & 0.073 & $<\mathrm{DL}$ & $<\mathrm{DL}$ & $<\mathrm{DL}$ & 0.680 & 0.060 & $<\mathrm{DL}$ & $<\mathrm{DL}$ & 0.138 & $<\mathrm{DL}$ & $<\mathrm{DL}$ & $<\mathrm{DL}$ & $<\mathrm{DL}$ \\
\hline 9 & 0.036 & 0.159 & 0.197 & $<\mathrm{DL}$ & $<\mathrm{DL}$ & $<\mathrm{DL}$ & 0.347 & 0.067 & $<\mathrm{DL}$ & $<\mathrm{DL}$ & 0.229 & $<\mathrm{DL}$ & $<\mathrm{DL}$ & $<\mathrm{DL}$ & $<\mathrm{DL}$ \\
\hline 10 & 0.099 & 0.075 & 0.076 & $<\mathrm{DL}$ & $<\mathrm{DL}$ & $<\mathrm{DL}$ & 1.130 & 0.049 & $<\mathrm{DL}$ & $<\mathrm{DL}$ & $<\mathrm{DL}$ & $<\mathrm{DL}$ & $<\mathrm{DL}$ & $<\mathrm{DL}$ & $<\mathrm{DL}$ \\
\hline 11 & 0.283 & 0.063 & 0.435 & 0.033 & $<\mathrm{DL}$ & $<\mathrm{DL}$ & 2.680 & 0.107 & $<\mathrm{DL}$ & $<\mathrm{DL}$ & 0.026 & $<\mathrm{DL}$ & $<\mathrm{DL}$ & $<\mathrm{DL}$ & $<\mathrm{DL}$ \\
\hline 12 & 0.495 & 0.048 & 0.028 & $<\mathrm{DL}$ & $<\mathrm{DL}$ & $<\mathrm{DL}$ & 0.125 & 0.086 & $<\mathrm{DL}$ & $<\mathrm{DL}$ & 0.048 & $<\mathrm{DL}$ & $<\mathrm{DL}$ & $<\mathrm{DL}$ & $<\mathrm{DL}$ \\
\hline 17 & 0.808 & 0.045 & 0.042 & 0.031 & $<\mathrm{DL}$ & $<\mathrm{DL}$ & 0.156 & 0.079 & $<\mathrm{DL}$ & $<\mathrm{DL}$ & 0.110 & $<\mathrm{DL}$ & $<\mathrm{DL}$ & $<\mathrm{DL}$ & $<\mathrm{DL}$ \\
\hline 18 & 0.041 & 0.154 & 0.176 & $<\mathrm{DL}$ & $<\mathrm{DL}$ & $<\mathrm{DL}$ & 0.320 & 0.063 & $<\mathrm{DL}$ & $<\mathrm{DL}$ & 0.058 & $<\mathrm{DL}$ & $<\mathrm{DL}$ & $<\mathrm{DL}$ & $<\mathrm{DL}$ \\
\hline 19 & $<\mathrm{DL}$ & 0.129 & 0.025 & $<\mathrm{DL}$ & $<\mathrm{DL}$ & $<\mathrm{DL}$ & 0.054 & 0.051 & $<\mathrm{DL}$ & $<\mathrm{DL}$ & $<\mathrm{DL}$ & $<\mathrm{DL}$ & $<\mathrm{DL}$ & $<\mathrm{DL}$ & $<\mathrm{DL}$ \\
\hline 20 & 0.251 & 0.115 & 0.213 & $<\mathrm{DL}$ & $<\mathrm{DL}$ & $<\mathrm{DL}$ & 0.761 & 0.045 & $<\mathrm{DL}$ & $<\mathrm{DL}$ & 0.047 & $<\mathrm{DL}$ & $<\mathrm{DL}$ & $<\mathrm{DL}$ & $<\mathrm{DL}$ \\
\hline 21 & 0.031 & 0.169 & $<\mathrm{DL}$ & $<\mathrm{DL}$ & $<\mathrm{DL}$ & $<\mathrm{DL}$ & 0.419 & 0.050 & $<\mathrm{DL}$ & $<\mathrm{DL}$ & $<\mathrm{DL}$ & $<\mathrm{DL}$ & $<\mathrm{DL}$ & $<\mathrm{DL}$ & $<\mathrm{DL}$ \\
\hline 22 & 0.565 & 0.055 & 0.716 & $<\mathrm{DL}$ & $<\mathrm{DL}$ & $<\mathrm{DL}$ & 0.165 & 0.064 & $<\mathrm{DL}$ & $<\mathrm{DL}$ & 0.129 & $<\mathrm{DL}$ & $<\mathrm{DL}$ & $<\mathrm{DL}$ & $<\mathrm{DL}$ \\
\hline 23 & 0.176 & 0.071 & 0.214 & 0.040 & $<\mathrm{DL}$ & $<\mathrm{DL}$ & 2.070 & 0.041 & $<\mathrm{DL}$ & $<\mathrm{DL}$ & 0.029 & $<\mathrm{DL}$ & $<\mathrm{DL}$ & $<\mathrm{DL}$ & $<\mathrm{DL}$ \\
\hline 24 & $<\mathrm{DL}$ & 0.146 & 0.027 & $<\mathrm{DL}$ & $<\mathrm{DL}$ & $<\mathrm{DL}$ & 0.123 & 0.043 & $<\mathrm{DL}$ & $<\mathrm{DL}$ & 0.052 & $<\mathrm{DL}$ & $<\mathrm{DL}$ & $<\mathrm{DL}$ & $<\mathrm{DL}$ \\
\hline 25 & 0.126 & 0.128 & $<\mathrm{DL}$ & $<\mathrm{DL}$ & $<\mathrm{DL}$ & $<\mathrm{DL}$ & 0.297 & 0.047 & $<\mathrm{DL}$ & $<\mathrm{DL}$ & 0.047 & $<\mathrm{DL}$ & $<\mathrm{DL}$ & $<\mathrm{DL}$ & $<\mathrm{DL}$ \\
\hline 26 & 0.056 & 0.068 & $<\mathrm{DL}$ & $<\mathrm{DL}$ & $<\mathrm{DL}$ & $<\mathrm{DL}$ & 0.179 & 0.026 & $<\mathrm{DL}$ & $<\mathrm{DL}$ & 0.049 & $<\mathrm{DL}$ & $<\mathrm{DL}$ & $<\mathrm{DL}$ & $<\mathrm{DL}$ \\
\hline 27 & 0.027 & 0.219 & 0.045 & $<\mathrm{DL}$ & 0.018 & $<\mathrm{DL}$ & 0.136 & 0.055 & $<\mathrm{DL}$ & $<\mathrm{DL}$ & 0.038 & $<\mathrm{DL}$ & $<\mathrm{DL}$ & $<\mathrm{DL}$ & $<\mathrm{DL}$ \\
\hline
\end{tabular}

Notes: ${ }^{a}$ Detection limit; Data values have a standard deviation less than $5 \%$.

Sr varied between 0.033 and $0.363 \mathrm{mg} \cdot \mathrm{L}^{-1}$. Concentrations of Fe range between $<\mathrm{DL}$ and $0.808 \mathrm{mg} \cdot \mathrm{L}^{-1}$, whereas those of $\mathrm{Al}$ varies between $<\mathrm{DL}$ and $2.68 \mathrm{mg} \cdot \mathrm{L}^{-1}$. The concentrations of Ba were low $(0.021-0.107$ $\left.\mathrm{mg} \cdot \mathrm{L}^{-1}\right)$. Finally, the $\mathrm{Cu}$ contents ranged from 0.026 to $0.230 \mathrm{mg} \cdot \mathrm{L}^{-1}$, except in six samples which had concentrations $<$ DL.

The household water samples contain a number of CFUs of variable TC and fall in the range of 0 to $16 \mathrm{CFU} / 100 \mathrm{~mL}$. The number of E. coli CFUs in the samples ranges from 0 to $8 \mathrm{CFU} / 100 \mathrm{~mL}$ (Table 3 ).

The chemical composition of water reaching households varies greatly and shows that during water distribution and storage, it undergoes important transformations. Comparing the household samples with sample 3 from the output of the WTP, the household water shows important variations in $\mathrm{pH}$, turbidity, $\mathrm{Fe}$ and $\mathrm{Al}$ contents as well as in TC and fecal coliforms (FC). Sample 3 does not present FC or TC but up to $8 \mathrm{CFU}$ of $E$. coli and up to $16 \mathrm{CFU}$ of TC were detected in the household water.

\section{Chemical composition of particulate matter}

Taxco potable water shows a notorious turbidity. Turbidity in household samples is generated by suspended particles generally of the size of clays $(<2 \mu \mathrm{m})$ and colloids $(<0.3 \mu \mathrm{m})$ resulting from an incomplete and/or inefficient flocculation process in the WTP. The results of partial extraction with $\mathrm{HNO}_{3}$ are presented in Table 4 .

\section{Sequential extraction}

The distribution of the analyzed metals $(\mathrm{Cd}, \mathrm{Co}, \mathrm{Cu}, \mathrm{Fe}, \mathrm{Mn}, \mathrm{Pb}$, $\mathrm{V}, \mathrm{Zn}$ and $\mathrm{As}$ ) in the sequential extraction is quite variable indicating that the metals are associated with different chemical fractions (Figure 3, Table 5). Cd, As and $\mathrm{Pb}$ are the metals of major ecotoxicological interest due to the effects they have on biota, including humans (Fergusson, 1990).

The element Cd is mainly associated with fraction 2 or carbonated fraction $\left(4.17 \mathrm{mg} \cdot \mathrm{kg}^{-1}\right)$, followed by fraction 5 or residual fraction $\left(1.88 \mathrm{mg} \cdot \mathrm{kg}^{-1}\right)$. The fraction of Cd bound to Fe-Mn oxyhydroxides (fraction 3) is lower at $0.744 \mathrm{mg} \cdot \mathrm{kg}^{-1}$, and the content in the exchangeable fraction (fraction 1) and those linked to sulfides and organic matter (fraction 4 ) is very low or $<$ DL of the method. Although Cd was not detected in fraction 1, which is the most available, the presence of this metal adsorbed to fractions 2 and 3 indicates that there is a moderate potential for releasing them. A change to lower $\mathrm{pH}(<5.5)$, as occurs in sample 11, will release $\mathrm{Cd}$ from the particulate matter.

The highest concentration of $\mathrm{Pb}\left(62.2 \mathrm{mg} \cdot \mathrm{kg}^{-1}\right)$ is associated with 
Table 3. Bacteriological analyzes of water samples from Taxco de Alarcón, Guerrero. Fecal coliforms correspond to E. coli.

\begin{tabular}{|c|c|c|}
\hline Sample & $\begin{array}{l}\text { Total coliforms } \\
\text { UFC/100 mL }\end{array}$ & $\begin{array}{c}\text { Fecal coliforms } \\
\text { UFC/100 mL }\end{array}$ \\
\hline 1 & 8 & ND \\
\hline 2 & $>100$ & $>20$ \\
\hline 3 & ND & ND \\
\hline 4 & 12 & 3 \\
\hline 5 & 7 & 1 \\
\hline 6 & 16 & 2 \\
\hline 7 & 1 & ND \\
\hline 8 & 13 & 8 \\
\hline 9 & 1 & ND \\
\hline 10 & ND & ND \\
\hline 11 & ND & ND \\
\hline 12 & ND & ND \\
\hline 13 & 7 & 3 \\
\hline 14 & ND & ND \\
\hline 15 & ND & ND \\
\hline 16 & ND & ND \\
\hline 17 & 4 & ND \\
\hline 18 & ND & ND \\
\hline 19 & ND & ND \\
\hline 20 & ND & ND \\
\hline 21 & ND & ND \\
\hline 22 & ND & ND \\
\hline 23 & ND & ND \\
\hline 24 & ND & ND \\
\hline 25 & ND & ND \\
\hline 26 & ND & ND \\
\hline 27 & 3 & 1 \\
\hline 28 & ND & ND \\
\hline 29 & ND & ND \\
\hline 30 & ND & ND \\
\hline 31 & 1 & ND \\
\hline 32 & 1 & ND \\
\hline 33 & ND & ND \\
\hline
\end{tabular}

ND: No detected.

the Fe-Mn oxyhydroxides fraction followed by the residual fraction $\left(17.15 \mathrm{mg} \cdot \mathrm{kg}^{-1}\right)$ and, to a lesser extent, in the fraction associated with sulfides and organic matter $\left(6.75 \mathrm{mg} \cdot \mathrm{kg}^{-1}\right)$. The exchangeable fraction and that associated with carbonates are below the DL of the method. Similar to Cd, the fraction associated with Fe-Mn oxyhydroxides will be released if the $\mathrm{pH}$ of the water decreases below 5.5. The $\mathrm{Pb}$ fraction associated with sulfides and organic matter will be more difficult to release since it requires values of $\mathrm{pH}<2.0$, conditions not registered in the samples studied.

Fortunately, total arsenic is associated with the residual fraction, so the likelihood of its release is extremely low.

$\mathrm{Co}, \mathrm{Fe}, \mathrm{V}$ and $\mathrm{Zn}$ have a similar speciation and differ only by the absolute concentrations in each fraction. These metals are mostly bound to the Fe-Mn oxyhydroxides fraction followed by the residual fraction and the fraction associated with sulfides and organic matter. The most available fractions ( 1 and 2 ) have the lowest concentrations in these metals ( 0.161 and $0.278 \mathrm{mg} \cdot \mathrm{kg}^{-1}$, respectively). In particular, the concentration of Co in fraction 3 and 5 (3.44 and $3.56 \mathrm{mg} \cdot \mathrm{kg}^{-1}$, respectively) are similar, whereas the concentration in fraction 4 is much lower $\left(0.576 \mathrm{mg} \cdot \mathrm{kg}^{-1}\right)$. The lowest Fe concentration was found in the exchangeable fraction $\left(0.176 \mathrm{mg} \cdot \mathrm{kg}^{-1}\right)$ and in that associated with carbonates $\left(0.388 \mathrm{mg} \cdot \mathrm{kg}^{-1}\right)$, whereas the highest concentration was found in the residual fraction $\left(7583 \mathrm{mg} \cdot \mathrm{kg}^{-1}\right)$, followed by fraction 3 (4873 $\left.\mathrm{mg} \cdot \mathrm{kg}^{-1}\right)$, and finally fraction $4\left(49.53 \mathrm{mg} \cdot \mathrm{kg}^{-1}\right)$. The lowest concentrations of $\mathrm{V}$ were found in fractions 1 and $2\left(0.012 \mathrm{mg} \cdot \mathrm{kg}^{-1}\right)$ and the highest concentration was found in fraction $5\left(31.34 \mathrm{mg} \cdot \mathrm{kg}^{-1}\right)$. In fraction 3 the concentration of $\mathrm{V}$ is $16.4 \mathrm{mg} \cdot \mathrm{kg}^{-1}$. Finally, in fraction 4 the content of $\mathrm{V}$ is $4.59 \mathrm{mg} \cdot \mathrm{kg}^{-1}$. The content of $\mathrm{Zn}$ is variable; the fraction with the highest content is 3 followed by fraction 5 . The lowest content of $\mathrm{Zn}$ was found in the exchangeable fraction. The $\mathrm{Zn}$ concentrations in the rest of the fractions are less than $10 \mathrm{mg} \cdot \mathrm{kg}^{-1} . \mathrm{Cu}$ and $\mathrm{Mn}$ have a similar distribution. The highest concentration of $\mathrm{Cu}$ and $\mathrm{Mn}$ is found in fraction 3, followed by fraction 5 and the lowest concentration is found in fraction 1 (Figure 3).

\section{DISCUSSION}

\section{Household water quality with respect to NOM-127-SSA1-1994 standard}

Table 6 shows a comparison between the physicochemical and bacteriological parameters analyzed in household water samples and the permissible limits established in the NOM-127-SSA1-1994 standard. Samples 19 and 26 are the only two samples that met the standard. Figure 4 shows the spatial distribution of samples that exceed permissible limits in turbidity, $\mathrm{Al}, \mathrm{pH}, \mathrm{Fe}, \mathrm{FC}$ and TC (Figure 4a-4f, respectively), established in the NOM-127-SSA1-1994 standard.

The $\mathrm{pH}$ is one of the physicochemical parameters with the greatest influence on water chemistry. It controls the conductivity, TDS content, alkalinity, hardness and metal content, among other parameters. In this study, the $\mathrm{pH}$ plays an important role in the interaction of water with the distribution pipes, an acid $\mathrm{pH}$ causes the dissolution of metallic materials of the pipe; in the case of pipes of different materials, e.g. plastic or cement, the effect is less. Also, a high $\mathrm{pH}$ causes the accumulation of precipitates.

Turbidity is important due to the fact that suspended particles are mainly composed of clays and organic matter, which have a high retention capacity of potentially toxic elements such as metals and As. Under reducing conditions, the toxic elements retained in the clays become soluble; and therefore, their concentration in water increases (Romero, 2001).

On the other hand, the high $\mathrm{Al}$ contents recorded in the potable water samples has its origin in the $\mathrm{Al}_{2}\left(\mathrm{SO}_{4}\right)_{3}$ used in the WTP for the flocculation process. At least 19 samples exceed the maximum permissible limit in the standard $\left(0.20 \mathrm{mg} \cdot \mathrm{L}^{-1}\right)$ reaching up to 13.4 times the permissible limit, as in sample 11 (Figure 5a). Any excess of this reagent will be solubilized and ionic aluminum will be released.

Table 4. Concentration of metals extractable with $\mathrm{HNO} 3$ in particulate matter of household tap water sample 13.

\begin{tabular}{lcccccccccccccccc}
\hline Element & $\mathbf{K}$ & $\mathbf{C a}$ & $\mathbf{M g}$ & $\mathbf{B a}$ & $\mathbf{S r}$ & $\mathbf{A l}$ & $\mathbf{C u}$ & $\mathbf{F e}$ & $\mathbf{M n}$ & $\mathbf{P b}$ & $\mathrm{Zn}$ & $\mathbf{V}$ & $\mathbf{C r}$ & $\mathbf{C o}$ & $\mathbf{N i}$ & As \\
\hline $\begin{array}{l}\text { Concentration } \\
\left(\mathrm{mg} \cdot \mathrm{kg}^{-1}\right)\end{array}$ & 927 & 3922 & 1106 & 103 & 32.19 & 53000 & 1069 & 9765 & 301 & 126 & 74.5 & 35.14 & 13.54 & 3.86 & 0.24 & 38.12 \\
\hline
\end{tabular}



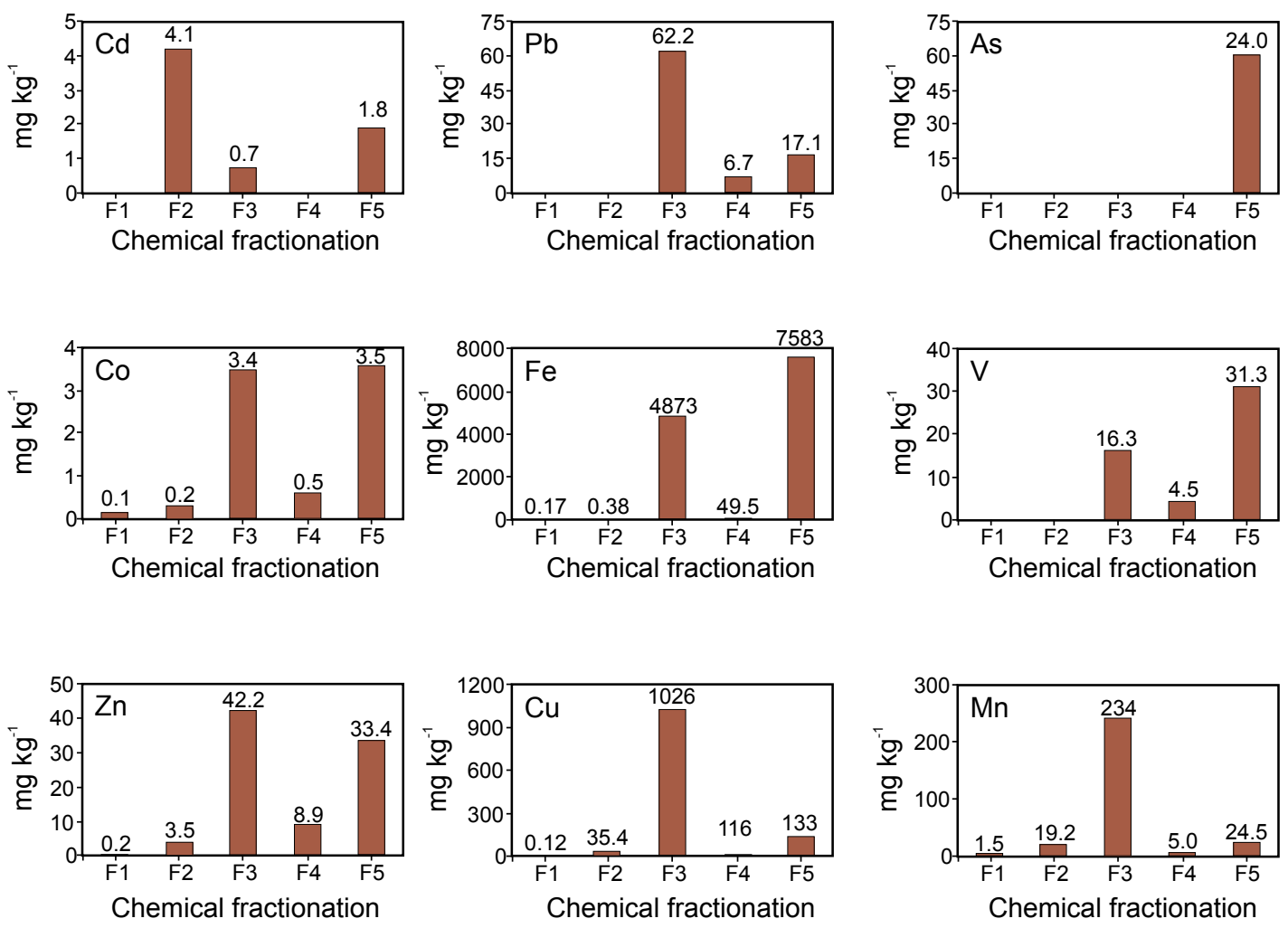

Figure 3. Chemical speciation of the potentially toxic elements detected in the particulate matter of one household tap water sample from Taxco de Alarcón. F1: Exchangeable fraction (soluble + adsorbed); F2: Fraction bound to carbonates; F3: Fraction associated with Fe-Mn oxyhydroxides; F4: Fraction bound to sulfides and organic matter; F5: Residual fraction (insoluble).

The accumulation of aluminum in the brain correlates with the onset of Alzheimer's (Emsley, 1998). On the other hand, the presence of iron $(\mathrm{Fe})$ can be explained by the fact that the water from the WTP has a slightly acidic $\mathrm{pH}$, probably dissolving Fe from the distribution pipelines. At least four samples exceed the permissible limit of 0.30 $\mathrm{mg} \cdot \mathrm{L}^{-1}$ and reach up to 2.7 times the permissible limit (Figure 5b). Although $\mathrm{Fe}$ is an essential element for humans in small doses

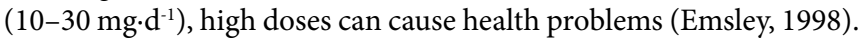

Finally, fecal coliforms (FC) are subdivided into subgroups and one of them is E. coli which is a bacteria found in human and animal feces, therefore, when the water contains E. coli, it indicates that the water could have been contaminated with human or animal feces, and this represents a health risk (Edberg et al., 2000). The treated water of the WTP did not show the presence of TC or E. coli. There are some factors that can lead to the pollution with coliforms. The water treated in the WTP is distributed to the households using the gravity force. Nevertheless, the difference of height between the WTP and the households results in high pressure in the water network, thus pressure reducing boxes are necessary. Those boxes are found outside throughout the city and are not hermetically sealed and represent a source of contamination for the treated water. On the other hand, most of the households store the water in tanks that not receive maintenance. Thus, the contamination is related to water transportation or storage in tanks at homes.

Table 5. Chemical fractionation in particulate matter of household tap water sample 13.

\begin{tabular}{|c|c|c|c|c|c|c|c|c|}
\hline \multirow[t]{2}{*}{ Element } & \multicolumn{5}{|c|}{ Concentration $\left(\mathrm{mg} \cdot \mathrm{kg}^{-1}\right)$} & \multirow{2}{*}{$\frac{\text { Total }}{\left(\mathrm{mg} \cdot \mathrm{kg}^{-1}\right)}$} & \multirow{2}{*}{$\frac{\text { TD }^{\mathrm{f}}}{\left(\mathrm{mg} \cdot \mathrm{kg}^{-1}\right)}$} & \multirow{2}{*}{$\frac{\text { Recovery }}{(\%)}$} \\
\hline & $\mathrm{F} 1^{\mathrm{a}}$ & $\mathrm{F} 2^{\mathrm{b}}$ & $\mathrm{F}^{\mathrm{c}}$ & $\mathrm{F} 4^{\mathrm{d}}$ & $\mathrm{F}^{\mathrm{e}}$ & & & \\
\hline $\mathrm{Cd}$ & $<0.5$ & 4.17 & 0.744 & $<0.5$ & 1.88 & 6.79 & 5.62 & 121 \\
\hline Co & 0.161 & 0.278 & 3.44 & 0.576 & 3.56 & 8.01 & 8.03 & 100 \\
\hline $\mathrm{Cu}$ & 0.124 & 35.4 & 1026 & 116 & 133 & 1311 & 1087 & 121 \\
\hline $\mathrm{Fe}$ & 0.176 & 0.388 & 4873 & 49.5 & 7583 & 12506 & 13811 & 91 \\
\hline $\mathrm{Mn}$ & 1.51 & 19.3 & 243 & 5.09 & 24.6 & 293 & 296 & 99 \\
\hline $\mathrm{Pb}$ & $<0.5$ & $<0.05$ & 62.2 & 6.75 & 17.2 & 86.1 & 141 & 61 \\
\hline V & 0.012 & 0.012 & 16.4 & 4.59 & 31.3 & 52.3 & 48.8 & 107 \\
\hline $\mathrm{Zn}$ & 0.285 & 3.58 & 42.3 & 8.96 & 33.5 & 88.6 & 97.3 & 91 \\
\hline As & $<0.5$ & $<0.5$ & $<0.5$ & $<0.5$ & 24.0 & 24.0 & 18.7 & 128 \\
\hline
\end{tabular}

${ }^{\mathrm{a}}$ Exchangeable fraction (soluble + adsorbed) ${ }^{\mathrm{b}}$ Fraction bound to carbonates; ${ }^{\mathrm{c}}$ Fraction associated with oxyhydroxides of Fe-Mn;

${ }^{\mathrm{d}}$ Fraction bound to sulfides and organic matter; ${ }^{\mathrm{e}}$ Residual fraction (insoluble); ${ }^{\mathrm{f}}$ Metal content in total digestion. 
Table 6. Range values of physicochemical parameters of Taxco de Alarcón household tap water, compared with the permissible limits in NOM-127-SSA1-1994 standard.

\begin{tabular}{lccc}
\hline Parameter & Range of values & $\begin{array}{c}\text { Permissible limit in the } \\
\text { standard }\end{array}$ & $\begin{array}{c}\text { Number of samples that exceed } \\
\text { the standard }\end{array}$ \\
\hline $\mathrm{Al}\left(\mathrm{mg} \cdot \mathrm{L}^{-1}\right)$ & $0.039-2.68$ & 0.200 & 19 \\
$\mathrm{As}\left(\mathrm{mg} \cdot \mathrm{L}^{-1}\right)$ & $0.010-0.018$ & 0.05 & 0 \\
$\mathrm{Ba}\left(\mathrm{mg} \cdot \mathrm{L}^{-1}\right)$ & $0.021-0.107$ & 0.700 & 0 \\
$\mathrm{Cd}\left(\mathrm{mg} \cdot \mathrm{L}^{-1}\right)$ & $<0.005$ & 0.005 & 0 \\
$\mathrm{E}$ Coli $(\mathrm{UFC} / 100 \mathrm{~mL})$ & $0-8$ & 0 & 6 \\
Total coliforms $(\mathrm{UFC} / 100 \mathrm{~mL})$ & $0-16$ & 0 & 11 \\
Chlorides $\left(\mathrm{mg} \cdot \mathrm{L}^{-1}\right)$ & $0.940-63.5$ & 250 & 0 \\
Copper $\left(\mathrm{mg} \cdot \mathrm{L}^{-1}\right)$ & $0.026-0.230$ & 2.00 & 0 \\
Total hardness $(\mathrm{CaCO})\left(\mathrm{mg} \cdot \mathrm{L}^{-1}\right)$ & $25.83-104$ & 500 & 0 \\
$\mathrm{Fe}\left(\mathrm{mg} \cdot \mathrm{L}^{-1}\right)$ & $0.027-0.808$ & 0.300 & 4 \\
Fluoride as $\left.\mathrm{F}^{-}\right)\left(\mathrm{mg} \cdot \mathrm{L}^{-1}\right)$ & $0-0.300$ & 1.50 & 0 \\
$\mathrm{Mn}\left(\mathrm{mg} \cdot \mathrm{L}^{-1}\right)$ & $0.023-0.088$ & 0.15 & 0 \\
$\mathrm{Nitrates}$ as N $\left(\mathrm{mg} \cdot \mathrm{L}^{-1}\right)$ & $0.500-2.0$ & 10 & 5 \\
$\mathrm{pH}$ & $5.2-8.8$ & $6.5-8.5$ & 0 \\
$\mathrm{~Pb}\left(\mathrm{mg} \cdot \mathrm{L}^{-1}\right)$ & $<0.025$ & 0.025 & 0 \\
$\mathrm{Na}\left(\mathrm{mg} \cdot \mathrm{L}^{-1}\right)$ & $2.78-36.75$ & 200 & 0 \\
Total dissolved solids $\left(\mathrm{mg} \cdot \mathrm{L}^{-1}\right)$ & $69.9-314.5$ & 1000 & 0 \\
Sulfates $\left(\mathrm{mg} \cdot \mathrm{L}^{-1}\right)$ & $1.10-70.5$ & 400 & 0 \\
$\mathrm{Zn}\left(\mathrm{mg} \cdot \mathrm{L}^{-1}\right)$ & $0.027-0.916$ & 5.0 & 24 \\
Turbidity $(\mathrm{NTU})$ & $3-93$ & 5.0 & \\
\hline
\end{tabular}

\section{Potential affectation by the toxic elements contained in the suspended particles}

The distribution of the analyzed elements $(\mathrm{Cd}, \mathrm{Co}, \mathrm{Cu}, \mathrm{Fe}, \mathrm{Mn}, \mathrm{Pb}$, $\mathrm{V}, \mathrm{Zn}$ and $\mathrm{As}$ ) in the different chemical fractions of the particulates vary greatly. Although the chemical behavior of these elements is variable and depends on the chemical fraction, their presence in the suspended particles in the household water represents a potential risk to the health of the users if the polluted water is drank.

Under acidic conditions and reduced Eh, the metals are soluble (Tessier et al., 1979; Fergusson, 1990). If the metals are in a basic medium and with an oxidizing Eh, they will oxidize and become insoluble. In the case of Taxco de Alarcón, $90 \%$ of the water that reaches the houses presents a circum-neutral to slightly basic $\mathrm{pH}$ (6.5-9.0) and an oxidizing Eh. Therefore, it is very likely that the metals remain insoluble and are retained in the suspended particles.

The elements contained in the exchangeable fraction represent the most soluble elements and, therefore, have greater bioavailability. The amount of metals adsorbed or retained on the surface of a mineral depends on the surface area of each mineral. On the other hand, the type of adsorbed metals depends on the Point Zero Charge (PZC) of each mineral and the $\mathrm{pH}$ of the medium in which they are found (Manning and Goldberg, 1996). For example, the PZC of Fe oxides ranges from 5 to 8 . When the $\mathrm{pH}$ of the water is lower than the PZC of Fe oxides, the surface of this mineral is positively charged, thus attracting all negatively charged compounds and retaining them on its surface. In contrast, when the $\mathrm{pH}$ of the water is higher than the PZC, the surface of this mineral is negatively charged releasing the negatively charged elements and retaining positively charged metals. The particulate matter has low but significant concentrations of $\mathrm{Co}, \mathrm{Cu}, \mathrm{Fe}, \mathrm{Mn}, \mathrm{V}$ and $\mathrm{Zn}$ in the exchangeable fraction, which will become soluble with small changes in the physicochemical conditions of the water.

The elements associated with the carbonate fraction are considered to be moderately bioavailable. $\mathrm{A} \mathrm{pH}<6.5$ is required to release the elements associated with this fraction. The matter has high concentrations of $\mathrm{Cd}, \mathrm{Cu}$ and $\mathrm{Mn}$, and smaller but significant in $\mathrm{Co}, \mathrm{Fe}, \mathrm{V}$ and $\mathrm{Zn}$, in the fraction associated with carbonates. Samples 3, 10, 11 and 23 have $\mathrm{pH}$ values $<6.5$ and represent the highest potential for releasing these elements associated with the carbonate fraction.

In the Fe-Mn oxyhydroxide fraction, the associated elements are considered to be moderately bioavailable. In this case, the elements contained could be released into the environment when the $\mathrm{pH}$ of the medium reach values $<5.5$. In the analyzed particulate matter, high concentrations of $\mathrm{Cu}, \mathrm{Fe}, \mathrm{Mn}, \mathrm{Pb}, \mathrm{V}$, and $\mathrm{Zn}$, and lower concentrations of Co, were detected in the fraction of oxyhydroxides. Sample 11 is the only one that has a $\mathrm{pH}$ value $<5.5$. However, the elements contained in this fraction will become bioavailable when the water undergoes additional important external transformations (Fergusson, 1990).

The elements bound to the fraction of sulfides and organic matter are considered to have low bioavailability. Extreme $\mathrm{pH}$ conditions $(<2.0)$ are necessary for release the elements. This situation is unlikely to occur in both the distribution system and the homes. As an example, an acid $\mathrm{pH}(\sim 1)$ is reached in gastric juices. In environments like these, the elements associated to sulfides and organic matter fraction represent a potential hazard. Fortunately, tap water is not usually used for drinking. The elements associated to the fraction of sulfides and organic matter in the particulate matter are $\mathrm{Cu}$ and $\mathrm{Fe}$ and in smaller proportion $\mathrm{Co}, \mathrm{Mn}, \mathrm{Pb}, \mathrm{V}$ and $\mathrm{Zn}$.

Finally, the elements associated with the residual fraction are considered non-bioavailable because they are associated with silicate minerals with a very low solubility product, and require extreme physicochemical conditions over a long period of time. The elements associated with this fraction do not represent a potential danger for biota. In the particulate matter, all the analyzed elements are present in this fraction and stand out for their concentration: $\mathrm{Fe}\left(7583 \mathrm{mg} \cdot \mathrm{L}^{-1}\right)$ and, due to its toxicological importance, $\mathrm{Pb}\left(17.15 \mathrm{mg} \cdot \mathrm{L}^{-1}\right)$ and $\mathrm{As}$ $\left(24.0 \mathrm{mg} \cdot \mathrm{L}^{-1}\right)$. The latter was only detected in residual fraction so it does not represent a potential danger to the inhabitants. 

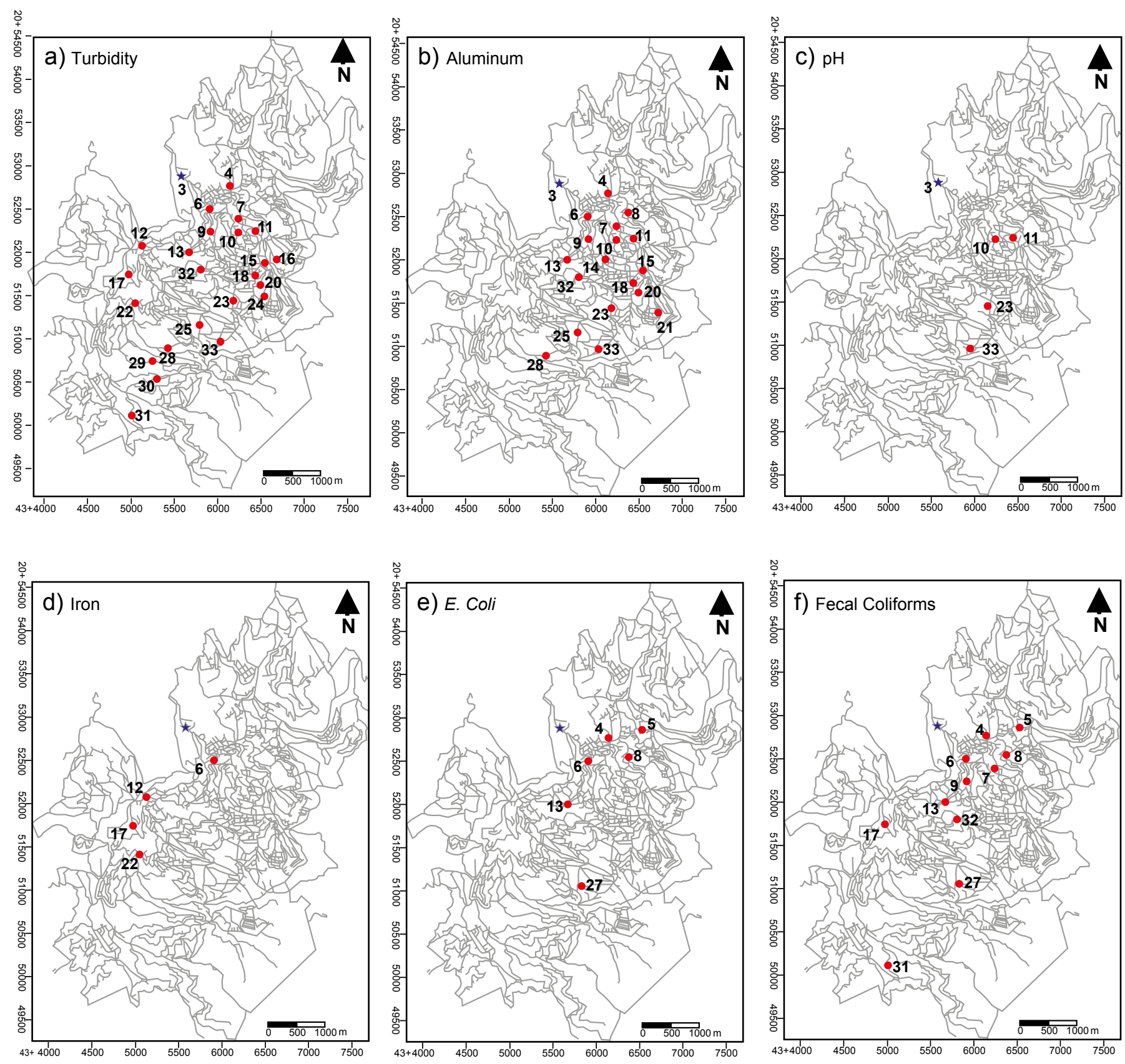

Figure 4. Location of sampling sites of household water samples that do not meet the permissible limits established in the NOM-127-SSA1-1994. Blue star is the location of the water treatment plant.

\section{CONCLUSIONS}

The water supply to the city of Taxco de Alarcón comes from surface water from rivers, dams and springs of the zone. The main supply comes from the Chontalcuatlán river, the springs of Chacuhalco and Tenería within the city, and from the San Marcos and El Sombrerito dams. The obtained and analyzed results indicate that the water quality from these sources is not adequate for potable use because the Chacuhalco spring presents turbidity levels above the NOM-127SSA1-1994. In addition, eight CFU/100 mL of TC were detected. Mixed water from Chontalcuatlán river water, the Tenería spring, and the San Marcos and El Sombrerito dams is not suitable for human consumption since they do not comply with Mexican regulations; they exceed the limits in barium and have more than $20 \mathrm{FC}$ and more than $100 \mathrm{CFU} / 100 \mathrm{~mL}$ TC. For these reasons, the water from these sources is treated in the WTP before sending the water to the homes. Unfortunately, the chemical analyzes carried out in the plant's output water indicate that the treatment process is inefficient because the water sent to the homes is slightly acidic ( $\mathrm{pH}$ 5.7), below the range established in the Mexican standard (6.5-8.5). Furthermore, suspended particles were observed, which results in a very high turbidity value ( 32 NTU) compared to that established in the standard (5 NTU). On the other hand, the output water contains high concentrations of $\mathrm{Al}\left(1.82 \mathrm{mg} \cdot \mathrm{L}^{-1}\right)$ that exceed the maximum permissible limit in the standard $\left(0.200 \mathrm{mg} \cdot \mathrm{L}^{-1}\right)$ in up to 9 times.

Particulate matter is characterized by high concentrations of total 

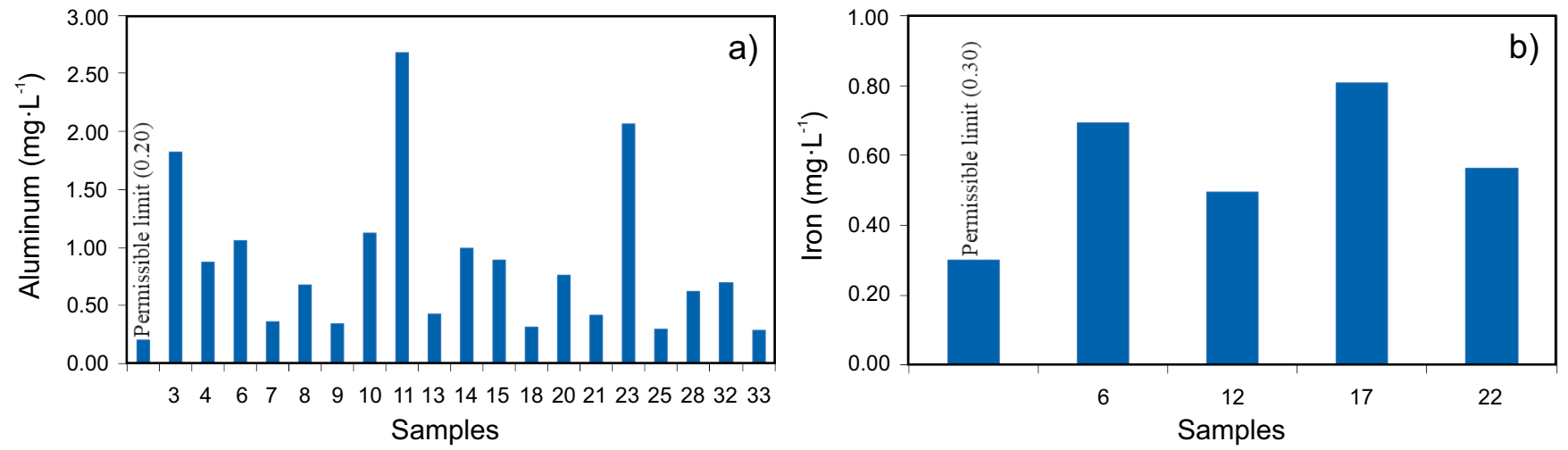

Figure 5. Samples that exceed the permissible limits established in the Official Mexican standard NOM-127-SSA1-1994. a) Aluminum, and b) iron.

metals (Al, $\mathrm{Cu}, \mathrm{Fe}, \mathrm{Pb}, \mathrm{As}, \mathrm{Cr}, \mathrm{V}, \mathrm{Zn}, \mathrm{Sr}, \mathrm{Ni})$. The speciation showed that $\mathrm{Cu}, \mathrm{Mn}, \mathrm{Zn}, \mathrm{Co}, \mathrm{V}$ and $\mathrm{Fe}$ have different concentrations in the exchangeable fraction and carbonate-associated fraction. Cd is associated with the carbonate fraction; the $\mathrm{Pb}$ is in the fraction associated with Fe-Mn oxyhydroxides, whereas the As is in the residual fraction, which is the most stable chemical fraction.

Finally, samples 19 and 26 from households were the only two samples that meet the Official Mexican Standard (NOM-127-SSA1-1994) in all measured parameters. However, overall the results provide information on the quality of potable water in the city of Taxco de Alarcón and indicate that modifications must be carried out in the water treatment processes, especially in the distribution network and water storage tanks, so that the water meets the standards of quality established by current regulations.

\section{ACKNOWLEDGMENTS}

The authors gratefully acknowledge the input and suggestions of the Editor and Reviewers, which allowed us to significantly improve the manuscript. Part of this contribution was part of a bachelor thesis by Guadalupe Sánchez Montoya. The authors also thank Travis Deane Ashworth for reviewing the English version of the paper.

\section{REFERENCES}

Cifuentes, E., Blumenthal, U.J., Ruiz-Palacios, G., Bennett, S., Peasey, A., 1994, Escenario epidemiológico del uso agrícola del agua residual: el Valle del Mezquital, México: Salud Pública, México, 36(1), 3-9.

CONAGUA (Comisión Nacional del Agua), 2016, Situación del Subsector Agua Potable, Drenaje y Saneamiento Edición 2016: Ciudad de México, Secretaría de Medio Ambiente y Recursos Naturales, Comisión Nacional del Agua, 189 pp.

CRM (Consejo de Recursos Minerales) 1999, Monografía geológico-minera del Estado de Guerrero: Pachuca, Hgo., Mexico, Secretaría de Comercio y Fomento Industrial, Consejo de Recursos Minerales, Publicación M-19e, 262 pp.

Corona-Chávez, P., Maldonado, R., Ramos-Arroyo, Y.R., Robles-Camacho, J., Lozano-SantaCruz, R., Martínez-Medina, M., 2017, Geoquímica y mineralogía de los jales del distrito minero Tlalpujahua-El Oro, México, y sus implicaciones de impacto ambiental: Revista Mexicana de Ciencias Geológicas, 34(3), 250-273. doi: http://dx.doi.org/10.22201/ cgeo.20072902e.2017.3.540.

Corrales-Pérez, D., Martín-Romero, F., 2018, Adecuaciones para mejorar la aplicación del método D3987-85 en la extracción de EPT de los antiguos residuos mineros El Fraile, Guerrero, México: Revista Mexicana de Ciencias Geológicas, 35(1), 1-17. doi: http://dx.doi.org/10.22201/ cgeo.20072902e.2018.1.536.

Covarrubias, S.A., Peña Cabriales, J.J., 2017, Contaminación ambiental por metales pesados en México: problemática y estrategias de fitorremediación: Revista Internacional de Contaminación Ambiental, 33, 7-21. doi 10.20937/RICA.2017.33.esp01.01.

Des Rivières, J., Beals, D., 2011, The Taxco mining District. Mineralogical: Record, 42(5), 401-445. doi: http://dx.doi.org/10.22201/cgeo.20072902e.2018.1.536.

Durfor, C.N., Becker, E., 1964, Public Water Supplies of the 100 Largest Cities in the United States, US Geog. Sur: Water Supply Paper, 1812, 364 pp.

Edberg, S.C., Rice, E.W., Karlin, R.J., Allen, M.J., 2000, Escherichia coli: the best biological drinking water indicator for public health protection: Journal of Applied Microbiology, 88, 106S-116S.

Emsley, J., 1998, The elements: Oxford University Press, Oxford Chemistry Guides, v. 2, 292 pp.

Fergusson, J.E., 1990, The heavy elements: Chemistry, environment impact and health effects: Oxford, England, Pergamon Press, $614 \mathrm{pp}$.

Gómez-Álvarez, A., Villalba-Atondo, A., Acosta-Ruíz, G., Castañeda-Olivares, M., Kamp, D., 2004, Metales pesados, en el agua superficial del Rio San Pedro durante 1997 y 1999: Revista Internacional de Contaminación Ambiental, 20(1), 5-12.

Gordillo-Martínez, A.J., Cabrera-Cruz, R.B.E., Hernández-Mariano, M., Galindo, E., Otazo, E., Prieto, F., 2010, Evaluación regional del impacto antropogénico sobre, aire, agua y suelo. Caso: Huasteca Hidalguense, México: Revista Internacional de Contaminación Ambiental, 26(3), 229-251.

Hernández-Flores, G., Solorza-Feria, O., Poggi-Varaldo, H.M., 2017, Bioelectricity generation from wastewater and actual landfill leachates: A multivariate analysis using principal component analysis: International Journal of Hydrogen Energy, 42(32), 20772-20782, http://dx.doi. org/10.1016/j.ijhydene.2017.01.021.

INEGI (Instituto Nacional de Estadística, Geografía e Informática), 2013, Perfil sociodemográfico, Estados Unidos Mexicanos, Censo de Población y Vivienda 2010: México, INEGI, 110 pp.

Literathy, P., 1996, Industrial wastes and water pollution: Regional Approaches to Water Pollution and Environment, Nato ASI Series, 20, 21-32.

Lu, J.L., 2011, Insecticide residues in eggplant fruits, soil, and water in the largest eggplant-producing área in the Philippines: Water, Air and Soil Pollution, 220(1-4), 413-422.

Manning, B.A., Goldberg, S., 1996, Modeling Arsenate Competitive Adsorption on Kaolinite, Montmorillonite and Illite: Clays and Clay Minerals, 44(5), 609-623.

Massoudieh, A., Bombardelli, F.A., Ginn, T.R., 2010, A biogeochemical model of contaminant fate and transport in river waters and sediments: Journal of contaminant hydrology, 112, 103-117.

Secretaría de Salud, 2000, Modificación a la Norma Oficial Mexicana NOM-127SSA1-1994, Salud ambiental. Agua para uso y consumo humano. Límites permisibles de calidad y tratamientos a que debe someterse el agua para su potabilización: Ciudad de México, Diario Oficial de la Federación, 22 de noviembre de 2000, 73-79. 
Pulido-Bosch, A., 2007, Nociones de hidrogeología para ambientólogos: España, Universidad de Almería, $492 \mathrm{pp}$.

Qu, X., Alvarez, P.J.J., Li, Q., 2013, Applications of nanotechnology in water and wastewater treatment: Water research, 47, 3931-3946.

Romero, M.F., 2001, Procesos Geoquímicas de liberación y trasporte de metales pesados y metaloides en residuos mineros (jales): México D.F., México, Universidad Nacional Autónoma de México, tesis de doctorado, 76 pp.

Romero, F.M., Armienta, M.A., González-Hernández, G., 2007, Solid-phase control on the mobility of potentially toxic elements in an abandoned lead/zinc mine tailings impoundment: Applied Geochemistry, 22, 109-127.

Sjömander Magnusson, T., van der Merwe, B., 2005, Context driven policy design in urban water management. A case study of Windhoek, Namibia: Urban Water Journal, 2(3), 151-160.

Smith, K.S., Huyck, H.L.O., 1999, An overview to the abundance, relative mobility, bioavailability and human toxicity of metals, in Plumlee, G.S., Logsdon, M.J. (eds), The Environmental Geochemistry of Mineral Deposits: Reviews in Economic Geology, 6A, 29-70.

Sun, H., Shi, B., Yang, F., Wang, D., 2017, Effects of sulfate on heavy metal release from iron corrosion scales in drinking water distribution system: Water Research, 114, 69-77.
Talavera-Mendoza, O., Armienta-Hernández,, M.A., Garcia-Abundis, J., Flores-Mundo, .N., 2006, Geochemistry of leachates from the El Fraile sulfide tailings piles in Taxco, Guerrero, southern Mexico: Environmental Geochemistry and Health, 28, 243-255.

Talavera-Mendoza, O., Ruiz J, Díaz-Villaseñor, E., Ramírez-Guzmán, A., Cortés A., Salgado-Souto, S.A., Dótor-Almazán, A., Rivera-Bustos,. R., 2016, Water-rock-tailings interactions and sources of sulfur and metals in the subtropical mining region of Taxco, Guerrero (southern Mexico): A multi-isotopic approach: Applied Geochemistry, 66, 73-81.

Tessier, A., Campbell, P.G.C., Bisson, M., 1979, Sequential Extraction Procedure for the speciation of particulate trace Metals: Analytical Chemistry, 51(7), 845-851.

Manuscript received: june 1, 2018

Corrected manuscript received: december 15, 2018

Manuscript accepted: january 9, 2019 